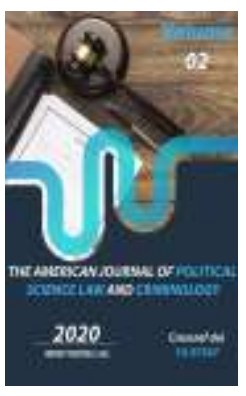

\title{
Units Of Psychological Operations: History Of Creation And Modern Trends
}

\author{
Shukhratjon Shakirov \\ Specialized Branch Tashkent State University Of Law Tashkent, Uzbekistan
}

Journal Website: http://usajournalshub.c om/index,php/tajpslc

Copyright: Original content from this work may be used under the terms of the creative commons attributes 4.0 licence.

\section{ABSTRACT}

The article deals with the creation of subdivisions of psychological operations in different historical epochs of time, trends in their development, the use of various forms and methods, along with the formation of the theory of psychological operations itself, as well as their role and place in the achievement of individual societies and states of their own goals and objectives.

\section{KEYWORDS}

Psychological operations, psychological warfare, informational and psychological influence, propaganda, apparatus, politics, state, society, man, war, conflict.

\section{INTRODUCTION}

Units of psychological operations (PsO), perhaps not in the current modern interpretation, began to be created simultaneously with the theory of the appearance of PsO back in ancient times.

So, at different times, taking into account the level of development of mankind, including scientific and technological progress, the characteristics and capabilities of various kinds and levels of associations, states, their geopolitical location and interests, as well as many other factors and conditions, PsO was carried out in all possible ways and methods, and the bodies and divisions had different names, structures, compositions, goals and objectives, respectively.

In this regard, the creation of organs and subdivisions of $\mathrm{PsO}$ in the historical plane should be considered in parallel with the 
formation of the theory of psychological operations itself.

Today there are many interpretations of this activity. At the same time, according to many experts, one of the most developed interpretations of the theory of PSYO is considered to be the American and Russian (Western and Eastern).

According to the charters and instructions of the US Armed Forces, psychological surgery is understood as measures to influence certain groups of people and individuals with the help of the media, various types of print, audio or video production, as well as through personal communication, in order to induce in them such a mood or behavior that promoted to achieve political and military goals. Leaders of political and public organizations, religious communities, the most influential representatives of the business community, the military elite and the creative intelligentsia are considered the main objects of influence. Activities may also cover military personnel, workers, peasants, technical intelligentsia and government officials.

The concept of "psychological operations", according to the views of American military experts, has a broad and narrow interpretation.

In a broad sense, psychological operations are understood as the planned use of means, forms and methods of disseminating information to exert a certain impact on the attitudes and behavior of a person. Such operations consist of political, military and ideological activities. They are carried out in line with state policy, and their military side is coordinated with the activities of the relevant government agencies.

More narrowly, psychological operations are used by the armed forces to demoralize and disorient the enemy. In addition, PsO contribute to the consolidation, information support and strengthening of the morale of the population and personnel of the Armed Forces of allied and friendly states [1].

According to the field manual of the US Army, psychological operations are planned propaganda and psychological activities conducted in peacetime or war, designed to target foreign hostile, friendly or neutral audiences in order to influence their attitudes and behavior in a favorable direction to achieve both political and US military national goals [2].

In NATO countries, the entire range of measures of information and psychological impact on the troops and population of the enemy is also denoted by the term "psychological operations" and is interpreted in almost the same way as the American approach [3].

Many Russian sources note that psychological warfare (synonymous with psychological operations) is a psychological impact on the enemy troops (forces) and the population in order to demoralize them and induce them to end resistance. It can be carried out in preparation for and during military operations.

According to I. Nepomnyashchy, psychological warfare is a special type of preparation and waging of wars, allowing the ruling circles, using propaganda, terror and other means, to influence their own peoples, the peoples of enemy, allied and neutral countries in the political, ideological, moral and psychological relation to achieve the goals of their military strategy [4].

Psychological operations were carried out already in armed clashes of tribes in the era of decay of the primitive communal system and in wars of slave-owning states. 
In the history of the ancient world, the most common way to influence the enemy and undermine his morale was intimidation with his combat power. For example, Genghis Khan and Hannibal, even before the start of the battle, deliberately spread rumors about "secret weapons" - war elephants, "fire snakes", poisonous smoke, etc.

Before going to Greece in $480 \mathrm{BC}$ the Persian commander Xerxes, in order to maximize the emotional impact on the enemy, spread rumors about the large number of his army, and also through influencing the corresponding priests, informed about imminent defeat [5].

This activity was first described in China 500 BC in one of the oldest treatises on the art of war. The author of the treatise, the famous commander Sun Tzu, outlined the main methods of influencing the psyche and behavior of the enemy [5]. At the same time, the entire doctrine of the conduct of PsO in Ancient China was based on the philosophical teachings of Lao Tzu ${ }^{1}$ in which great attention was paid to influencing the strategy and diplomacy of the enemy, demonstrating one's own strength and abandoning blind faith in luck.

Another Chinese treatise on strategy, The Six Arts of Warfare, provides an example of a staff structure. Of the 72 staff members of the headquarters, 19 (26\%) were responsible for conducting PsO. At the same time, five of them promoted the power of the army, four praised the valor of their troops, eight scouted the intentions of the enemy, and two contributed to the emergence of a feeling of insecurity among his soldiers, undermining their faith in gods and spirits [6].

${ }^{1} \mathrm{VI}$ century $\mathrm{BC}$.
In the slave-owning period, the experience of warfare was generalized in India in the form of the "Laws of Manu", which, along with military issues, set forth the moral foundations of war. According to one of the recommendations of the "Laws of Manu", the belligerent side should actively "encourage the mutiny of those of the enemy troops who are inclined to this".

This period in the field of the formation of the theory of PsO on the enemy gave a lot, the method of intimidation and spread of rumors for this purpose reached a certain perfection. In a primitive form, an understanding arose of the importance of exacerbating contradictions in the enemy camp and introducing a split in its ranks. The use of such a technique as the proclamation of the just nature of the war on its part and the unjust, enslaving nature of the enemy was developed.

Despite the fact that the methods of psychological influence for military purposes have been known since ancient times, psychological warfare in its modern sense arose and took shape only in the 2oth century. World War I marked a turning point in the development of the theory and practice of $\mathrm{PsO}$.

At the very beginning of the war, the governments of the belligerent countries, with the exception of Germany, came to the conclusion that it was necessary to create special bodies to conduct PsO.

In 1914, under the Ministry of Foreign Affairs of England, a military propaganda bureau was created, later the military information department, which was later transformed into the Ministry of Information, carrying out propaganda among the military personnel and the population of foreign countries. In 1915, a military propaganda service department was 
created at the General Staff of the French Ministry of Defense, whose task was to influence the enemy with the help of leaflets, and in 1917, the United States joined the conduct of psychological warfare, creating the so-called. "Psychological section".

Russia, Italy and other countries, to a certain extent, tried to exert an information and psychological impact on the troops and population of the enemy, but it was significantly inferior to the British and French.

In Germany, until August 1918, it was forbidden to engage in the publication and distribution of leaflets, since, according to the country's leadership, this was contrary to the rules of war. Only a newspaper published in French for the population of the occupied regions was allowed, which was distributed with the help of balloons beyond the front line. When the ban was lifted, Germany began the mass publication of leaflets [7].

In general, during the First World War, PsO was mainly conducted through the dissemination of printed propaganda. As a first experience at the front lines, attempts were also made to conduct oral broadcasting through loudspeakers.

This war became the starting point in the formation of the theory of PsO, the states' awareness of their effectiveness in achieving their goals and protecting their interests, the creation of appropriate units and doctrinal foundations.

The Second World War tested the viability of theoretical propositions about the effectiveness of PsO. The main forms during the war were printed and radio propaganda.

\footnotetext{
${ }^{2}$ According to the instruction No. 51/39 of 1939.
}

It was the results of the First World War that contributed to the systemic understanding of the need to create structured bodies and units with the task of implementing $\mathrm{PsO}$, and the second became a "platform" for their application and testing.

So, for these purposes, the following were created: in the USSR - the Bureau of MilitaryPolitical Propaganda, Great Britain - the Executive Committee of Political War, the USA - the Bureau of Military Information, in Germany - the Ministry of Public Education and Propaganda [8].

After the National Socialist Party came to power in Germany, this ministry was formed, a propaganda department was created at the headquarters of the Supreme Command, to which special units were subordinated propaganda companies, designed to conduct propaganda among the German population and the enemy's military personnel ${ }^{2}$. In 1943, the propaganda troops became an independent branch of the military, their number reaches 15 thousand [9].

The experience of conducting propaganda during the Second World War is a significant contribution to the theory and practice of PsO in combat conditions, once again confirms the enormous importance and possibilities of this activity as an effective means of undermining the morale and fighting spirit of enemy troops. The special importance of $\mathrm{PsO}$ is also confirmed by the fact of purposeful creation for these purposes of the corresponding supreme management bodies and divisions.

With the technological level of development of many countries after the experience of the Second World War, PsOs received significant 
development, their implementation intensified in almost all regional and local conflicts.

Wars and local conflicts of the late XX - early XXI century clearly confirm the tendency for the role of non-combat forms of confrontation to increase. Moreover, if earlier they were used to create favorable conditions for the use of military force, now and in the future to achieve political and strategic goals without the use of military force.

In modern conditions, almost all countries have special structures responsible for PsO. However, at the present time, like the two main theories of $\mathrm{PsO}$, there are more developed models of the apparatus (organs) ${ }^{3}$ of psychological warfare - western and eastern (Soviet).

This model is fully or partially implemented in the USA, Germany, Great Britain, France, Belgium, the Netherlands, Sweden, Turkey, Israel, South Korea, and a number of other Western countries.

The most powerful and professionally trained apparatus for psychological impact on the enemy is at the disposal of the armed forces of the United States, Germany and Israel. In wartime, PsO units are supposed to be deployed to full staff in the Armed Forces of Great Britain, France, Belgium, Sweden, Turkey, South Korea.

Bodies of psychological warfare in Western states are called units of "psychological operations" (USA, Great Britain, South Korea),

${ }^{3}$ The apparatus of psychological warfare is the governing bodies of it and the people (officers, specialists, military units) who carry it out. It must be capable of rapid deployment, operational monitoring of the situation in various regions, and the ability to perform assigned tasks in any conditions. $\begin{array}{lcr}\text { "operational } & \begin{array}{c}\text { information" } \\ \text { defense" }\end{array} & \begin{array}{r}\text { (FRG), } \\ \text { (Sweden), } \\ \text { "psychological }\end{array} \\ \text { "psychological } & \begin{array}{c}\text { warfare" } \\ \text { (Turkey), }\end{array} \\ \text { "psychological support" (Israel) [10]. } & \end{array}$

The apparatus of psychological warfare of Western states is focused on solving specific problems in the event of crisis situations in certain regions and during the war. In peacetime, this apparatus is engaged in analytical research, informing the troops, working with the public and the press, preparing information and reference and propaganda materials, planning strategic psychological operations. In the context of peacekeeping activities, PsO units can also be deployed, as is the case in Bosnia, where the United States created a special PsO group "Eagle".

The apparatus of psychological warfare of Western states is usually part of the Armed Forces and is directly subordinate to their general staffs (headquarters of the Armed Forces). The main documents, according to which psychological warfare measures are carried out in Western states, are special charters and manuals (for example, the FM 355 "Psychological Operations" charter in the USA, KDV-100-200 "Manual on the conduct of psychological defense" in Sweden, etc. ).

The organizational and staff structure of the $\mathrm{PsO}$ units is not permanent. In its construction, the concept of a modular structure is applied. Depending on the specifics of the combat

The apparatus of psychological warfare has its own structure, which depends on the historical traditions of the country and its armed forces, the specific experience they have accumulated during previous military conflicts [10]. 
situation and the tasks assigned by the command, appropriate units are created.

The main unit of the Western states is the PsO battalion. There are four types of such battalions: regional battalions; training and distribution battalions; battalions of tactical PsO; battalions for work with enemy prisoners of war (interned civilians).

Battalions, depending on their mission and specific tasks, include companies, centers, platoons, sections, formed from functional teams of 27 types. The teams, in turn, are divided into three large groups: headquarters and management, supply and maintenance, operational (tactical) [11].

The eastern model of psychological warfare organs has been fully or partially implemented in Russia, China, Vietnam, India, Iraq, Syria and North Korea. Its difference from the Western model is that in the Armed Forces of these countries, PsO units are basically a special staff and practically unchanged staff of headquarters (Russia, India, Iraq) or political bodies of all degrees (Vietnam, China, North Korea, Syria).

Bodies of psychological warfare of the Eastern states are called apparatus of "psychological support" in Russia (in Soviet times until 1992 "special propaganda"), "psychological operations" in India, "political work among the troops and population of the enemy" in China, Vietnam, North Korea, "political propaganda among the troops and population of the enemy" in Syria.

In peacetime, these bodies study the militarypolitical and socio-psychological situation in various regions of the countries of interest to the leadership, and in the border states, inform their troops, work with the public and the press, prepare information, reference and propaganda materials, plan strategic PsO.
Organizational and staff units for conducting $\mathrm{PsO}$ in the armed forces of the eastern states are departments (divisions, directorates) that are part of the headquarters or political agencies, propaganda detachments and special editions.

Departments (departments, directorates) of $\mathrm{PsO}$, as a rule, are available in all combinedarms formations, starting with the corps, and are designed to plan and manage PsO. Propaganda detachments are intended mainly for sound and radio broadcasting. Editorial offices for the preparation of information and propaganda materials are usually staff units of districts and headquarters of the Armed Forces in peacetime, combined-arms armies in wartime.

In general, the theory and practice of PsO, under the influence of a whole complex of objective and subjective factors, has gone through a difficult evolutionary path in the historical plane - from the perception of this activity as an auxiliary tool used in solving combat missions at the tactical and operational levels, to giving them a global function of command and control of the armed conflicts at the strategic level.

One of the important means of achieving one's goals, along with the material component, has been given special attention since ancient times to the moral. The experience of all wars and conflicts clearly shows that their outcome ultimately depends on two factors - material and moral. Many countries fought against the enemy not only by armed means, but also by purposefully influencing the consciousness and psyche of people, i.e. purposeful production and dissemination of special information that has a direct impact on the functioning of the information and psychological environment of society, the psyche and behavior of the population, military 
personnel to weaken the morale and combat power of the enemy.

Analysis shows that PsO could and can be carried out not only during the preparation and conduct of wars and conflicts, as some experts claim. They were also carried out to achieve other goals in various spheres of the life of the individual, society and the state. Accordingly, PsO units or subjects of this area of activity could be part of various kinds of actors' activities, which depends on the goals and objectives pursued by them.

\section{REFERENCES}

1. Veprintsev VB, Manoilo AV, Petrenko Al, Frolov D.B. Operations of information and psychological warfare: a short encyclopedic dictionary. - M., 2005.

2. Field Manual of the US Army FM 33-1. Psychological operations.

3. Makarenko S.I. Monograph: Information confrontation and electronic warfare in network-centric wars at the beginning of the XXI century. - SPb., 2017.

4. Nepomniachtchi I. Psychological warfare: the history of the concept.

5. Historical aspects of the theory and practice of information and psychological impact.

6. Avramenko A., Starunsky A. Foreign Military Review, 2005, No. 4.

7. Morozov A. Psychological war has returned a lot to the old course.

8. Historical aspects of the theory and practice of information and psychological impact.

9. Makarenko S.I. Monograph: Information confrontation and electronic warfare in network-centric wars at the beginning of the XXI century. - SPb., 2017.
10. Olevsky V. NATO psychological operations doctrine (2016). Foreign Military Review, 2016, No. 6.

11. Krysko V.G. Secrets of psychological warfare (goals, objectives, methods, forms, experience). Publisher: Minsk 1999. 